\title{
Right To The Difference Space As The City Magnet (The Study of Teory Henri Lefebvre)
}

\author{
Morida Siagian \\ Department of Architecture, Faculty of Engineering \\ University of Sumatera Utara \\ Medan, Indonesia \\ pohontepiair@gmail.com
}

\begin{abstract}
The phenomenon occured in urban area is the phenomenon of space. This phenomenon can not be separated from the contradictive interests. The contradiction is caused due to conflicts in the life of society and capitalism. The clash occurred between the two sides lies in the use of space between use-value of living brought bycommunity and exchange-value of caiptalism brought by the capitalists. The purpose of this paper is to explain a space phenomenon at the city through a review of the theory of Henri Lefebvre about differencial space. The struggle of the community in the city always bring up new space (right to the different space) become to "Meeting Place" between these two values. That "Meeting Place" not only can unite the needs between these two values, but also become the city magnet.
\end{abstract}

Key Word :Space; Mutual Space; Difference Space; Magnetism

\section{INTRODUCTION}

Every era has a different tendency according to the spirit of his time. The modernist look the urban spaces as the result of their idealistic thought as part of its responsibility to enhance the quality of human life. However, various situations do not correspond to the expectation of the modernism designer (Setiawan, 2015). For example, the manifestation of modernism in the context of the growth of shopping mall in big cities of Indonesia, that almost as certainned around the shopping center (high business) is the appearance of a petty business area spread sporadically, clumped in land. Such as food vendors, mobile pulse up to illegal parking lot. The existence of this activity certainly is damaging the ideal design of a shopping center with the concept of unity of function which does not provide small business spaces outside the area.

Modernism is characterized by change, inovation and dynamism. In the modernization, it is believed that save humans from the darkness and save human from the exploitation and suppression (Barker, 2000). That is why modernism revere of science and logic to certain truth which are valid in all the time, space and cultural differences. Scientific knowledge and experts are seen as universally truths in creating humanitarian welfare (Rudianto; Sutrisno, 2005).
The dynamics of modernism has brought globalization that cause social relations separated from their local context. With the tecnological advances of modernism fades tradition and replace it with a new one. This has led to an imbalance between human being with the environment around it. Personal freedom in every city increased, but the same time everyone is get loosing himself. According Sudaryono (2008) growing business centers, luxury residential complex, apartments and hypermarkets as well as fried chicken make a word cities lost his true identity. Modernism makes the human be driven, not engaged in urban space. Based on the growth, cities are becoming homogeneous. Function and system driven for the purposes of the capitalist as a man in power of space.

Wirth (in Barker, 2000) wrote that the globalization of capitalism leads to lost of the cultural diversity. City life is marked by ignorance of each other. Residents of the city then form groups based on similarities in lifestyle, cultural, tribal and consequently there is no sense of belonging. Globalization produces cultural homogenization consequenctly social relations with neighbors are getting lost.

Henry Lefebvre attempted to give a new perspective towards the contradiction the space in the development of the city. He articulates that the phenomenon that occurs in urban areas is the phenomenon of space. He state in his book "The Production of Space" (1991), that the problems of space in modern cities are caused by conflict in the life of society and capitalism. The conflict between the two sides lies in the use value of living brought by community owned and exchange value brought by capitalist. These spaces always show the contradiction between community with the qualitative space and the capitalist with the quantitative space.

This contradiction occurs when the qualitative value owned by human right manipulated by the quantitative value owned by government and capitalist so that modern space always is contradictive with the local space. It is because maintain local space means to maintain 
their identity, this struggle then produces a new space as their meeting place. Lefebvre's critic of this meeting place is used as a reference to solving many problems of public space in the city.

\section{DISCUSSION}

Henry Lefebvre, an expert on sociology from France in the 19th century was the first brought the spaces in the production process. Lefebvre's thought is contrary to Marx, who discussion argued that the strength of production is in the powe of capital, labor and machine. Lefebvre stated the city has been formed by needs of supply and demand that are going on. Goods and machine are understood as the capitals power, while spaces where the production take place this is out from the attention of Marx.

Lefebvre argued that considerations of space is extremely important. He said that the space produce social relations, social relasions then produce social-space. According to Lefebvre space is something that economically determined by social capital, controlled by the owners of capital, and politically regulated by the goverment. He explained that the abstract space is the product of political power (government) and economic power (capitalist). Instead social space is something important for the community in everyday life. Thats is why abstract space and social space is contradictive.

Space is an important aspect of human life, culture influences the space, space not only determines the social life but also the power that exist in a society. Space does not occur automatically but produced by the society. Henry Lefebvre (2004), states that the city space can be analyzed by understanding their social relationships. The emergence of space cannot be separated from social life. Space is not only an output produced but also the means of production. The concept of Production of Space stated by Lefebvre is dialectic of space that includes three spaces (triad space), namely: the space of everyday life with the use value (perceived space), abstract space with exchange-value (conceived space) and space-social (lived-space) that occurs as a result of the social relationships.

The transformation of city space basically occurs due to the goverment intervention and capitalis exploitation throught the planning of two dimensions. The city master plan which abstract spaces (mental spaces) are come from the logic of thought by urban planners and architects are loaded with such a broad abstract value, location and the benefits that achieved (Siagian, 2012). The government and capitalists always work together for the profit. Capitalist oriented to increase profits, while the government accentuate the development as their success. The dependent of capitalist to government because of land ownership, so, goverment and capitalist produce abtract spaces (Gottdiener, 1985).

For purpose of public interest and development, capitalist and goverment use quantitative value than abtract spaces in to social spaces. That leads to conflicts between the two spaces. Qualitative value will disappear of weaken. When the qualitative value survive at the insistence of quantitative, then it appears the space consumption. This space is guarded by the government. At the time the space consumption and production space made the market then the whole space being quantitative.

Understood of Lefebvre is actually from the doctrine of the structured, Castells (structuralist) that told a city is an arena for the use of collective consumption, so that community service (settlements,- transportation, power) is the responsibility of the government. The government is also responsible for the quality of life as well as the regulations (Castells, 1997). The concept of the use of collective consumption developed by Castells opens wide government intervention in solving the problem of the city. The other thing that is opposed by Lefebvre was Harvey, also structuralist, who stated that the existence of a relationship between capital structure and the creation and use of the environment, culture, nature and ecology and space which must demolished for the capital rescue. Urban planning is a destruction of the local space and then replace it with the new space which is considered as a manifestation of the circulation of capital.

In the cities of development like as Jakarta, Surabaya and Medan in Indonesia, capital strength has been gripping the development. The public space of the city quickly switch function into a quasi public space owned by the holders of capital. Cities are no longer built with "The Power of Nature", but with the power of capitalists. The shopping center was created to provide service no other entertain-ment and recreation for workers in urban areas. They are working to improve economic status simply to meet their needs will be a space at the end of capital will flow back into the hands of the owners of capital.

Lefebvre was very concerned with the phenomenon of the capitalist powers that dominated, uniformed at once deadly urban differences. Thus the urban space according to Lefebvre is supposed to give the place on ethnic differences, tradition, religious groups because of 
different space is a mirror of the difference invalue. Urban spaces should provide in to the right to the difference space.

A conflict between modernity and locality in the city gave rise to new spaces which by Lefebvre is referred to as differential space. The configuration of the space within the city such as the existence of the city centre and the sub area (periphery), the presence of conceived space and imagined space show the struggle towards right to the city and right to the different space (Soja, 1996) The struggle to produce of new space as a "Meeting Places" rather than separation. This space into a meeting, and togetherness than the second value.

Case Study Right To The Difference Space as Emergence of Social Space in Medan, Indonesia

\section{Kampung Keling}

Initially Tamil community was immigrant who was brought to Indonesia as workers. The unveiling cooperation of tobacco fields in Tanah Deli between the Malays and the Dutch colonial government required a lot of manpower. So that in 1873 for the first time this tobacco fields received 25 Indian Tamil labors from the island of Penang and Singapore. To improve the performance of the workers, the Dutch colonial government run a social concept that consigns the area of Kampung Keling as a settlement for Tamil community. The determination of this location was the part of the design concept of Medan called 'quarter system' developed by the Netherlands in 1917 to divide the settlement zones based on ethnicity (Buiskol, 2004).

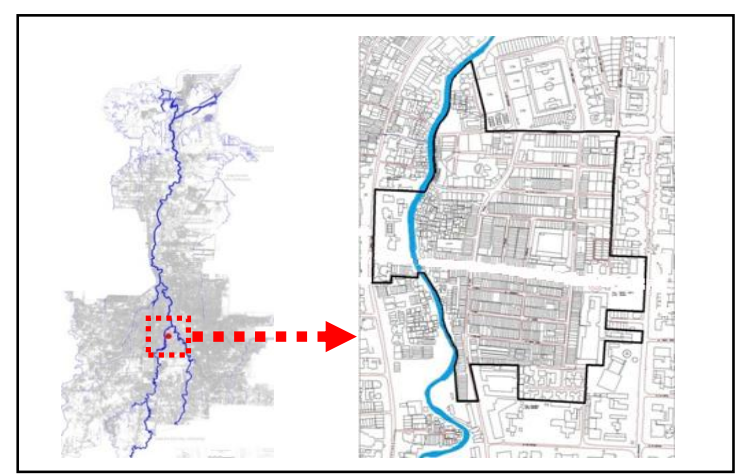

Fig. 1. Map of Kampung Keling

At the beginning of placement, the residential area in Kampung Keling was a village with houses that were separated each other with a large yard. There were shady trees everywhere and the paths were made of soil. Tamil community was gardening and raising cows, children were playing in the yard, mothers and fathers interacted in an open space. Every day they bathed and washed in the river. In every custom events and cultural and religious celebrations, they worked together in kinship. Tamil community runs their everyday life in the space they produced themselves. (Siagian, 2015).

Physically, the strategic location of Kampung Keling led this area to thrive from time to time. Since 1960s, most of Tamil community sold their lands and buildings to China community and they moved out to outside area. The remained of Tamil community lived in the dense and irregular periphery area in four villages along the Babura River in the west side area, namely: Dayak Village, Mayor Village, Kubur Village, and Madras Hulu Village. These villages are located behind the houses and shops houses adjacent to the river. Their houses are not directly visible from the road, but hide behind the shop houses owned by China.

I. Residential area of Tamil community A : Dayak Village

B : Mayor Village

C : Kubur Village

D : Madras Hulu Village

II. Commercial area of China community 


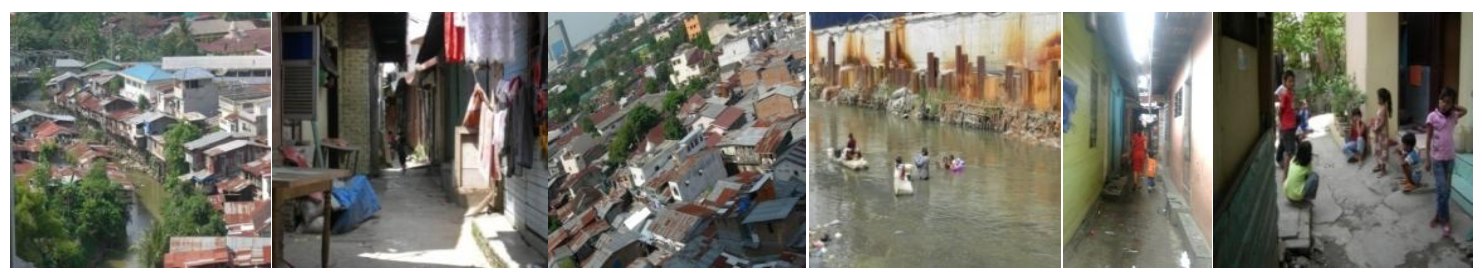

FIG. 2. Division Residential Tamil Communities At The Sub Area

In the other hand, since1970s, Kampung Keling was developed into the most elite commercial district in the city of Medan. In the era of the 2000s, Kampung Keling enlivened mega projects such as malls and hotels. Nowdays, $85 \%$ of Kampung Keling areas are occupied by the China community.

Modernity brought by the new comer China and the locality by local Tamil community as the initial people, present the different values and spaces in Kampung Keling. China community brings the exchange value in abstract space (conceived space), whilst Tamil community brings the use value in their everyday life space (perceived space). However, the social relations between the two communities unify both the different value and spaces into one space called social space. In this social space, the existence of the Tamil community as part of the city of Medan can be seen clearly.

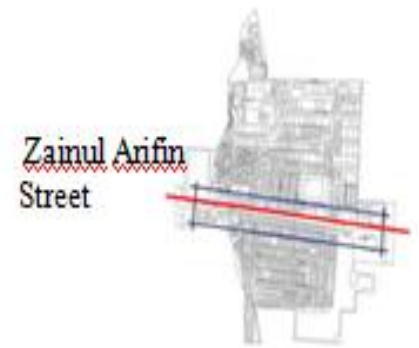

Key Plan

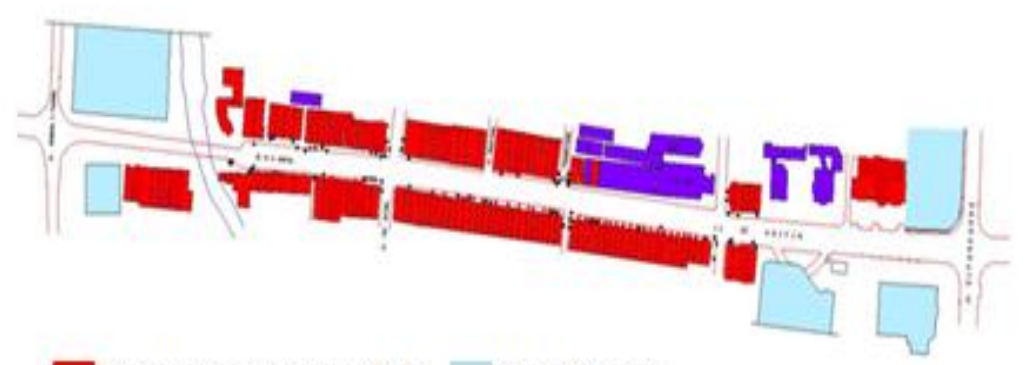

Shophouse/Commercial, Maga Project
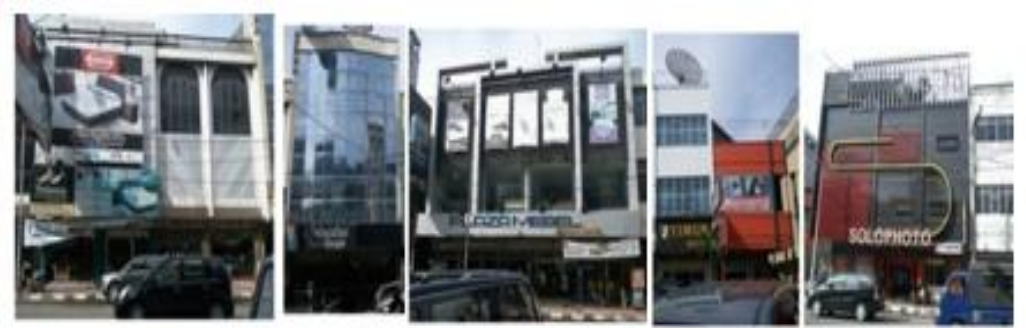

Shophouses at Zainul Arifin Street
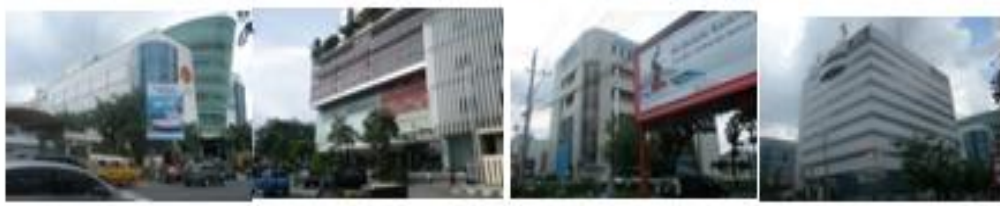

Mega Project at Zainul Arifin Street

\section{FIG. 3. Commercial building who settelement by China Community at the area.}

For China community, their commercial business in Kampung Keling can be more secured from the threat of racism and gangsterism with the presence Tamil community selling the fireworks sales stalls in front of their shops. Fireworks sales stalls also become an attraction for buyers. At the time a lot of people choose fireworks, they also indirectly attracted to come and visit the shops owned by China community.
This social spaces also are reviving business activities belonged to China community that weakened by the construction of the mega project in Kampung Keling. In this context, both Tamil and China communities mutually benefit. Social space produced from social relations of two communities in Kampung Keling describes the struggle of Tamil community in Kampung Keling in case of preserving their presence in the social 
changes. Social space is a place where the remained Tamil community strengthens their selves and establishes their identity in the periphery area. At this space, Tamil community can be present in the central area and becoming a part of the hustle of the city.

Social space is the strength of the area and becomes powerful magnet that attracts people of the city to come to Kampung Keling. The attraction comes from a social relationship between Tamil community and China community in the area without any intervention of the government or others. Until nowadays, Kampung Keling becomes a famous fireworks seller in the city of Medan. Even on New Year's Eve, this area becomes the center of the fireworks festival. Zainul Arifin Street becomes the gathering space for the community of the city of Medan.

\section{Pekan Labuhan}

The district of Pekan Labuhan is one of the important area in Medan. This place is oridinate in the old town area, the development of the Sultanate of Deli (1669) and become a business center in the Dutch Colonial era (1884). Malays community and China comunity had life side by side in this area. Malays comunity use space at the area for daily life (use value) who live in residential villages on the edge of the area and China run business (exchange value) in Jalan Syahbudin Yatim as the main street in the area.

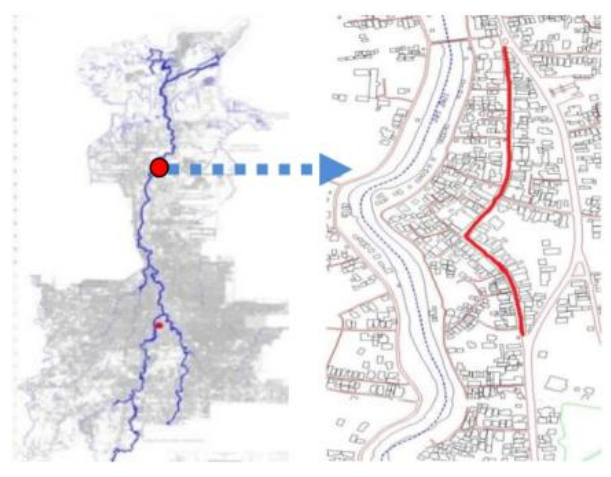

\section{FIG. 4. Map of Pekan Labuhan}

Malays and China build kinship hereditary family, cultural and religious activity. Previously The China community had a rich lifestyle because their business were growing at this place. While the Malays people went through life with sufficient income. Their works as fisherman and laborer. Interactions between China and Malays has increased due to the religious needs of China community and economic needs of Malays. The China community has a duty to give to others because of the demands of religious teachings, the gift is addressed to the Malays in their envirounment. There are two Pekongs ant the area, Pekong Liat Sim Kong (1872) and Pekong Siu San Keng (1890) as the old Buddish temple in Medan. The China community gave "Sembako" to the Malay community through both Pekong. This was well received by Malays and they always enthusiastic when there are the event of giving "Sembako".

Political incident in this area make the distortion of social space between Malays and China. Political incident that brought the issue of the Communist Party of Indonesia (PKI) in 1965 made threaten public security of non indigenous in Pekan Labuhan. And the incident of reformation in May 1998 threaten public security of non indigenous doing adeprivation of property and looting committed by youth gangs.

There two incidents at the area that caused China comunity moved out from the area, but there a few China family still remained living at the Pekong complex. Nowadays more than $60 \%$ of the community in Pekan Labuhan is Malays, less than 40 percent is Batak, and Javanese. After incident 1998, the China community moved out and sold shop-houses then these houses now are inhabited by Malay people and newcomers from indigenous pople. China does not dominate at this place, but rows of shophouses with China-style still are coloring the main spaces in the area.

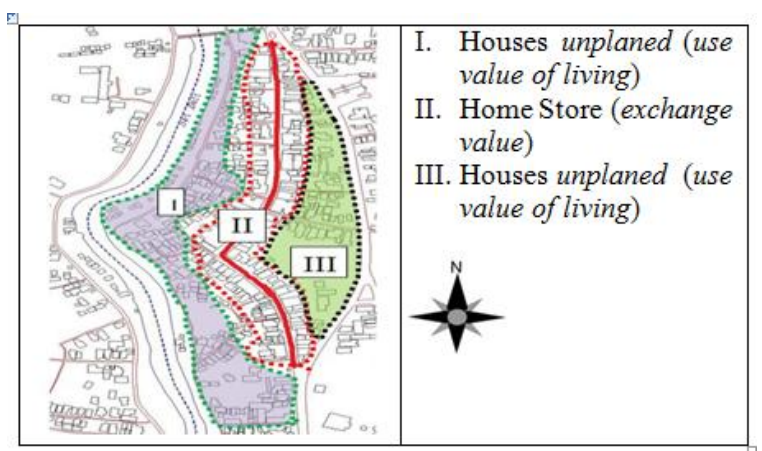

FIG.5. Using Space in the Area.

In incident May 1998, both Pekongs have survived from criminalization, eventhought China society do not live in this area, but they still exist. China people from various areas in Medan 
continuous come to this Pekong to do religious activity. For right to the difference space, China need safety for the pekong, so they let the Malays participate welcome to the big event held in both Pekongs. For China Pekong are important space (place) for their life in long term. For Malays, Pekong are place to get money and occasionally get advantages. These communities then have mutualistic relasionship at the area. For the reason each other they right to the different space to produce a social space.

Since the migration of China communities, Malays people and indigenous people who still live at the area, especially in the shop houses area are struggling to survive. Shop houses in the Jalan Syahbuddin Yatim now owned and managed by Malays families in to a market which the name "Pekong Market". Nowdays the market is run and controlled by Malays, however it still use the the name Pekong as the popular name.

Both Pekongs become media to present social relations of both communities. Pekong at the times has been able to be a marker of identity and becomes a "sense of place" between the two groups. The name of pekong to the market present the relationship between the two communities. Identity is created by the social space and produced by the China and Malays relationship. The social space is not created by the architect, but by the relationship of the comunities with their own interest.

\section{CONCLUSION}

Description of the urban space that capitalistic transactional refers to the condition of the community is more devastating to put forward a capital relationship compared to cultural relations. Henri Lefebvre's critique about the condition is expressed as spatial practices approritation physically agains space, it causes social relation can be intertwined, although transactional spaces still keep going. The space eventually becomes the community's powers in the social life. Space was created by the social relations in this space became the means of production. The space by capitalist as the exchange value and local people as the use value will be converge when the social relasionship occured and social space produced.
Social spaces that produced by social relations of people is one important part of the city. Shakespeare said that "why is the city?, the city is the people" next oscar lewis (1966) said that a picture of a city is also a picture of a society ", the city is by defenition any, a social image (Oscar Lewis, 1996).

\section{REFERENCES}

[1] Barker, Chris. "Cultural Studies, Theory and Practice". Sage Publications London. 2000.

[2] Broadbent, Geoffrey et al, "Meaning and Behaviour in the Built Environment" John Wiley \& Sons, Ltd, New York. 1980.

[3] Brodwin, Paul, "Marginality and Cultural Intimacy in a Transnational Haitian Community" Department of Anthropology, University of Wisconsin - Milwaukee. 2001.

[4] Carsten, Janet and Hugh-Jones, Stephen. "About The House. Cambridge University Press, Cambridge. 1995.

[5] Castells, Manuel, 1996, The Rise of The Network Society, Blackwell Publisher, Inc, Malden

[6] Castells, Manuel. "The Power of Identity" Blackwell Publisher, Inc, Malden. 1997.

[7] Gallon, Arthur B, FAIA and Eisner, Simon, APA, AICP. "The Urban Pattern" Van Nostrand Reinhold Company, New York. 1986.

[8] Gottdiener.M. "The Social Production of Urban Space" University of Texas Press. Austin. 1985.

[9] Lefebvre, Henri, "The Production of Space" Blackwell Publishing, Malden. 1991.

[10] Lincoln, Yvonna S. And Guba, Ego G., "Naturalistic Inquiry. Sage Publications Inc., Beverly Hills. 1985.

[11] Lynch, Kevin. "A Theory of Good City Form. The MIT Press, Cambridge. 1981.

[12] Madanipour, Ali. "Design of Urban Space" John Wiley \& Sons, New York. 1996.

[13] Mumford, Lewis. "The Culture of Cities" Harcourt Brace Jovanovich, Inc., New York. 1970.

[14] Rapoport, Amos. "The Mutual Interaction of People and Their Built Environment" Mouton Publishers, Paris. 1976.

[15] Rapoport, Amos."The Meaning of the Built Environment" The University Of Arizona Press, Tucson. 1982.

[16] Setiawan, andi. Produksi Ruang Sosial Sebagai Konsep Pengembangan Ruang Perkotaan. University of Sebelas Maret. Haluan Sastra Budaya. Vol 33, No 66. Semarang. 2015.

[17] Siagian, Morida. (2012). Regionalisme-Postmodern: Perjuangan Atas Hak yang Berdeda. Proceeding Seminar Nasional. Departemen Arsutektur, Universitas Sumatera Utara, Medan.

[18] Siagian, Morida. (2015). The Emergence of Social Space: Case Study From Kampung Keling, Medan, Indonesia. Conference of Urban Culture at the Cross Road, Dubrovnic, Austria.

[19] Siagian, Morida. (2015). Legacy in Social Space. AENSI Journals. Malang, Indonesia.

[20] Siagian, Morida (2015). Social Space as PeopleGathering Tool. Procedia. ASEAN-Turkey ASLI 2016.

[21] Sinar, Tengku Lukman S.H., 1991, The History of Medan in the Olden Times, Penerbit Perwira, Medan.

[22] Soja, Edward W., 1996, Thirdspace, Blackwell Publishers, Inc., Malden.

[23] Soja, Edward W 2004. Postmodern Geographies : The Reassertion of Space in Critical Social Theory. PrenticeHall.

[24] Sudaryono. “ Perencanaan Kota Berbasis Kontradiksi: Relevansi Pemikiran Henry Lefebvre Dalam Produksi Ruang Perkotaan Saat Ini". Jurnal Perencanaan Wilayah \& Kota, Vol. 19/No. 1. 2008. 